\title{
Behavioral and sociodemographic correlates of the body mass index in Brazilian workers
}

\author{
Correlatos comportamentais e sociodemográficos do índice de massa corporal em \\ trabalhadores brasileiros
}

\begin{abstract}
AUTHOR'S
Priscila Cristina dos Santos $^{1}$ (D)

Kelly Samara da Silva ${ }^{1}$ (D)

Bruno Gonçalves Galdino da Costa ${ }^{1}$ (iD

Gabrielli Thais de Mello ${ }^{1}$ (D)

Elusa Santina Antunes de Oliveira ${ }^{2}$ (D)

Markus Vinicius Nahas ${ }^{1}$ (D)

1 Federal University of Santa Catarina, Sports Center, Florianópolis, Santa Catarina, Brazil.

2 Federal Institute of Santa Catarina, Palhoça, Santa Catarina, Brazil.
\end{abstract}

\section{CORRESPONDING}

Priscila Cristina dos Santos

prisantos.personal@gmail.com

Rua Servidão Caminho dos Surfistas, 210,

Florianópolis, Santa Catarina, Brazil.

CEP: 88036-184.

\section{DOI}

$10.12820 /$ rbafs. $23 \mathrm{e} 0042$

\begin{abstract}
An unhealthy body composition has been linked with chronic diseases and premature deaths that could be prevented. It is desirable to understand how modifiable behaviors are linked to the body composition of industrial workers, and identify risk groups among the population to plan interventions and policies. The aim of the study was to identify the sociodemographic, physical activity, sedentary behavior, and nutritional correlates of the body mass index (BMI) of Brazilian industrial workers. Data were used from the "Lifestyle and Leisure Habits of Industrial Workers" study ( $\mathrm{n}=$ 45,508), conducted between 2006 and 2008, in 24 of the 27 Brazilian states. Gender, physical activity practice, television viewing, consumption of sweetened drinks, weight, and height were reported by the participants, and BMI was calculated. Linear regression analysis was conducted to identify the factors associated with BMI. Women had a lower BMI when compared to men $\left(-1.63 \mathrm{~kg} / \mathrm{m}^{2}\right.$, CI95\%: $-1.71 ;-1.56)$. Age and television viewing were positively associated with BMI and physically inactive adults had a BMI of $0.22 \mathrm{~kg} / \mathrm{m}^{2}(\mathrm{CI} 95 \%$ : $0.15 ; 0.29)$ greater than those who were active during leisure time. There was no association between BMI and sweetened drink consumption. Usually, BMI is higher among men, older individuals, those who watch more hours of TV daily, and those who do not practice physical activity during leisure time. When possible, it is suggested to promote the practice the practice of physical activity during leisure time without directing actions to comply with the recommendation of 150 minutes per week with the understanding that some activity is better than none, as well as stimulate the reduction of TV viewing time among workers.
\end{abstract}

Keywords: Obesity; Physical activity; Sedentary behavior; Sweetened drink consumption; Adult.

RESUMO

A composição corporal não saudável tem sido associada a doenças crônicas e morte prematura que podem, em parte, serem prevenidas. Dessa forma, destaca-se a importância de compreender como comportamentos modificáveis estão relacionados à composição corporal de trabalhadores da indústria e identificar quais são os grupos de risco. O objetivo do estudo foi identificar a relação entre fatores sociodemográficos, e comportamentais (atividade física, comportamento sedentário e consumo de refrigerante) com o indice de massa corporal (IMC) de trabalhadores brasileiros da indústria. Os dados são do projeto "Estilo de vida e hábitos de trabalho da indústria" ( $n=45.508$ ), realizado entre 2006 e 2008, em 24 estados brasileiros. Sexo, prática de atividade física, visualização de televisão, consumo de refrigerante, peso e a altura foram relatados pelos participantes. Análise de regressão linear múltipla foi aplicada para identificar fatores associados ao IMC. As mulheres apresentaram menor IMC quando comparado aos homens $\left(-1,63 \mathrm{~kg} / \mathrm{m}^{2}, I C 95 \%\right.$ : -1,71;-1,56). A idade e tempo de televisão apresentaram associação positiva com o IMC e os adultos fisicamente inativos apresentaram IMC de $0,22 \mathrm{~kg} /$ $m^{2}$ (IC95\%: 0,15;0,29) maior que aqueles ativos durante o tempo de lazer. Não houve associação entre o IMC e o consumo de refrigerante. O IMC tende a ser maior entre os homens, individuos mais velhos, aqueles que não praticam AF durante o tempo de lazer e despendem maior tempo assistindo TV diariamente. Portanto, sugerimos a promoção da atividade física sem direcionamento de ações para cumprimento das recomendaçôes de 150 minutos/semana, mas para a compreensão de que fazer alguma coisa é melhor do que nada. Ademais, sugerímos politicas para a redução do tempo de visualização de TV entre os trabalhadores.

Palavras-chave: Obesidade; Atividade física; Comportamento sedentário; Consumo de refrigerante; Adulto.

\section{Introduction}

Higher body mass indexes (BMI) have been associated with chronic diseases and all-cause mortality, this is important as the rising prevalence of overweight and obesity in several countries has been described as a glo- bal pandemic ${ }^{1}$. Therefore, the costs attributable to obesity worldwide are estimated to be between $0.7 \%$ and $2.8 \%$ of countries' total health budget ${ }^{2}$. In Brazil, this cost corresponds to $1.86 \%$ (US $\$ 269.6$ million in 2011) of the Ministry of Health's total expenditure related 
to hospital and ambulatory care ${ }^{3}$ and it seems that the higher the BMI, the greater the healthcare costs and lower productivity at work ${ }^{4}$. The impact of the increased BMI on people's health and on the health care system may be increased on specific subgroups such as workers, as work is often characterized by routine movements and gestures, inadequate postures and stresses derived from the productive system ${ }^{5}$. In addition, the increased BMI also impact people's quality of life $^{6}$, psychological health and, mental health ${ }^{7}$.

Brazilian industrial workers represent a large proportion of the country's population, and their health and quality of life is important, as they may already be at increased risk due to their occupational activities. Other habits may be important to help monitor their health and control their BMI. The industrial workers' health is also an economic issue, because when a worker is absent from his job, there are increased costs for the health system as well as costs related to missing days at work.

In Brazil, a change in law number $8.080^{8}$ includes physical activity (PA) as a determinant factor for health, and thus, is also important as a right of the worker. Other policies may also impact workers' habits and health, but it is not clear how their lifestyle differ from other workers and this subsequent impact on BMI. Research has shown that an increase in BMI is influenced by several factors such as gender, age, diet, PA and sedentary behaviors ${ }^{3,9}$. Many studies investigating BMI in countrywide samples were conducted in high-income countries $^{1}$. In higher-income countries, men are more likely to have increased BMI, whereas in lower- and middle-income countries, it seems that women are more likely to have increased $\mathrm{BMI}^{1}$. Moreover, it has been observed that BMI increases with old age ${ }^{10}$.

However, few studies have been conducted in lowand middle-income countries, which makes it difficult to gather evidence about these relationships ${ }^{10,11}$. Besides, there is evidence of a slowdown of increasing BMI rates in developed countries ${ }^{1}$. The influence of modifiable behavioral factors on increased BMI, for instance, implies that it could possibly be prevented, directly and indirectly, by eating healthier foods, increasing PA and reducing television viewing time ${ }^{3,9}$. Therefore, it is important to examine this relationship in specific populations of industrial workers in low- and middle-income countries, complementing the literature of the widely researched high-income countries.

The BMI, when analyzed without cut-off points, presents the possibility of better understanding the relationships between continuous BMI values and social and demographic factors. This information is more relevant to add to the understanding of health as an expanded and holistic concept that not only focuses on classifying people as healthy or sick but also works on ways to prevent and promote health. Therefore, this study aimed to examine the relationship between sociodemographic factors, PA, sedentary behavior, and sweetened drink consumption with the BMI of Brazilian industrial workers.

\section{Methods}

The present study conducted a secondary analysis of "Lifestyle and Leisure Habits of Industrial Workers" project, conducted by the Social Service for Industry Workers (SESI) and the Research Center for PA and Health (NuPAF), between 2006 and 2008. Data from workers in 23 states (the states of Rio de Janeiro, Sergipe, and Piauí were not included, as the data collection was not completed within the research schedule) and the Federal District were collected.

The sampling process was conducted independently for each federal unit, and the size was calculated to estimate leisure-time PA. The criteria for sample size estimation included $45 \%$ prevalence, $3 \%$ sampling error, $95 \%$ confidence interval, 1.5 design effect, and 20\% increase for losses and refusals. At the time of the data collection, the workers represented $24 \%$ of industrial workers in Brazil ${ }^{12}$. The sampling process was conducted in two stages with a random and proportionate selection of industries, considering the distribution of workers in large ( $\geq 500$ employees), medium (100 to $499)$ and small $(\leq 499)$ companies in the first stage. In the second stage, workers were selected proportionally according to the size of the industry, by systematic selection using lists provided by the companies with the names of its employees.

Participants were Brazilian industrial workers linked to the SESI system. These workers represent different industry branches such as civil construction, food, extractive, soda and meat, beverages, metal-mechanics industries among others. They answered a previously validated self-report questionnaire ${ }^{13}$ administered by trained researchers. The questionnaire was composed of four parts: personal and company information; health indicators and preventive behaviors; PA and leisure options; and control of body weight and eating habits. The companies that did not allow the 
administration of the questionnaires were replaced by companies of the same size and in the same region. To replace those selected workers who were not at the workplace at the time of data collection or who refused to participate, names were subsequently chosen from the list of employees provided by the companies. Both these replacement strategies were performed to minimize sample losses, which would rendered the study infeasible because of a lack of power and representativeness. Further information regarding the sampling methods can be found in other publication ${ }^{12}$.

The dependent variable was BMI, which was calculated by dividing self-reported weight (in kilograms) by the square of the height (in centimeters). The independent variables were gender (male or female), age ( $<30,30-39,40-49, \geq 50$ years), daily television viewing on weekdays ( $<2$ hours, $2-4$ hours, $>4$ hours), leisure-time PA (engaging at least once weekly or not engaging regularly) ${ }^{14}$, and artificially sweetened drink consumption (does not consume or consumes at least once a week $)^{15}$.

Absolute and relative frequency, as well as, mean its respective $95 \%$ confidence intervals (CI95\%) were used to describe the data. Linear regression analysis was conducted using BMI as a dependent variable and with simultaneous inclusion of all independent variables. The model was also adjusted for income $(<\mathrm{R} \$$ $600, \mathrm{R} \$ 601-\mathrm{R} \$ 1500, \mathrm{R} \$ 1501-3000,>\mathrm{R} \$ 3000)$, education (Incomplete Elementary school, Complete Elementary school, Complete High school and Complete Graduation) and the Federal Units ( $\mathrm{n}=23$ Brazilian States, and the Federal District). All analyses were conducted on Stata, version 13.0 (StataCorp, CollegeStation, TX, USA). Statistical significance was set at a $\mathrm{p}$ value $<0.05$.

The study was approved by the Research Ethics Committee of the Federal University of Santa Catarina, Brazil by the protocol 009/2007.

\section{Results}

A total of 47,886 workers of 2775 companies participated in the survey. The mean questionnaire return rate was $90.6 \%$. Four hundred and nine subjects $(0.9 \%$ of the total) were excluded because they had no response for gender, and another $4.0 \%$ did not report their weight and/or height. Therefore, data analysis was performed for 45,383 workers.

Table 1 presents the characteristics of the sample. The participants presented a mean BMI of $24.50 \mathrm{~kg} /$ $\mathrm{m}^{2}( \pm 0.18)$. The majority of participants was male ( $\mathrm{n}$ $=33,161,69.9 \%)$, younger than 30 years $(n=21,801$; $46.1 \%)$, watched more than 2 hours of $\mathrm{TV}$ per day $(\mathrm{n}=$ $15,920 ; 33.8 \%)$, and engaged in PA during leisure time $(\mathrm{n}=25,573 ; 54.6 \%)$.

Table 1 - Sociodemographic, behavioral and body mass index characteristics of Brazilian workers (2006-2008).

\begin{tabular}{|c|c|c|c|c|}
\hline Variables & $\mathrm{n}$ & Prevalence (\%) & \multicolumn{2}{|c|}{ CI95\% } \\
\hline$\overline{S e x}$ & 47,477 & & & \\
\hline Male & & 69.85 & 69.43 & 70.26 \\
\hline Female & & 30.15 & 29.74 & 30.57 \\
\hline Age (years) & 47,258 & & & \\
\hline$<30$ & & 46.11 & 45.66 & 46.56 \\
\hline $30-39$ & & 30.96 & 30.54 & 31.38 \\
\hline $40-49$ & & 16.80 & 16.46 & 17.14 \\
\hline$\geq 50$ & & 6.14 & 5.92 & 6.36 \\
\hline Educational level & 47,370 & & & \\
\hline Incomplete elementary school & & 18.93 & 18.58 & 19.29 \\
\hline Complete elementary school & & 15.67 & 15.35 & 16.00 \\
\hline Complete high school & & 51.03 & 50.58 & 51.48 \\
\hline Complete graduation & & 14.36 & 14.05 & 14.68 \\
\hline Income (reals) & 46,981 & & & \\
\hline$\leq 600$ & & 32.07 & 31.65 & 32.50 \\
\hline $601-1500$ & & 41.40 & 40.96 & 41.85 \\
\hline $1501-3000$ & & 17.49 & 17.15 & 17.83 \\
\hline$>3000$ & & 9.04 & 8.78 & 9.30 \\
\hline TV viewing time (hours) & 47,121 & & & \\
\hline$<2$ & & 42.85 & 42.41 & 43.30 \\
\hline $2-4$ & & 48.13 & 47.67 & 48.57 \\
\hline$>4$ & & 9.02 & 8.77 & 9.29 \\
\hline Leisure-time physical activity & 47,132 & & & \\
\hline At least once a week & & 54.61 & 54.16 & 55.06 \\
\hline Not engaging regularly & & 45.39 & 44.94 & 45.84 \\
\hline $\begin{array}{l}\text { Sweetened drink consumption } \\
\text { (week days) }\end{array}$ & 47,260 & & & \\
\hline No & & 12.64 & 12.34 & 12.94 \\
\hline 1 or more & & 87.36 & 87.06 & 87.66 \\
\hline Body mass index (mean) & 45,511 & $24.50^{*}$ & 24.47 & 24.59 \\
\hline
\end{tabular}

$\mathrm{n}=$ sample of each question answered in the questionnaire; CI95\% $=95 \%$ confidence interval

Women had a lower BMI compared to men $(-1.63$ $\mathrm{kg} / \mathrm{m}^{2}$, CI95\%: -1.71; -1.56). Age and TV viewing were positively associated with BMI and physically inactive adults had a BMI of $0.22 \mathrm{~kg} / \mathrm{m}^{2}$ (CI95\%: 0.15; $0.29)$ greater than those who were physically active during leisure time. There was no association between BMI and sweetened drink consumption in both men and women (Table 2). 
Table 2. Association between sociodemographic and behavioral variables with body mass index, adjusted by income and education of Brazilian workers. 2006-2008 $\left(n=45.383\right.$, adjusted $\left.r^{2}=0.11\right)$.

\begin{tabular}{lcc}
\hline \multicolumn{1}{l}{ Sex } & $\beta$ & CI95\% \\
$\quad$ Male & 1 & \\
$\quad$ Female & -1.63 & $-1.71 ;-1.56$ \\
Age (years) & & \\
$\quad<30$ & 1 & \\
$30-39$ & 1.37 & $1.29 ; 1.45$ \\
$40-49$ & 1.96 & $1.86 ; 2.05$ \\
$\geq 50$ & 2.04 & $1.89 ; 2.19$ \\
TV viewing time (hours) & & \\
$<2$ & 1 & \\
2 - 4 & 0.10 & $0.03 ; 0.17$ \\
$>4$ & 0.21 & $0.09 ; 0.33$ \\
Leisure-time physical activity & & \\
At least once a week & 1 & \\
Not engaging regularly & 0.22 & $0.15 ; 0.29$ \\
Sweetened drink consumption (week days) & & \\
No & 1 & \\
Yes & 0.05 & $-0.05 ; 0.15$ \\
\hline
\end{tabular}

\section{Discussion}

The observed average BMI of Brazilian workers was close to the overweight threshold for adults, suggesting a high BMI profile among this subgroup. The sociodemographic factors associated with BMI were gender and age, with men having a higher BMI and age being positively associated with BMI. Practicing PA during leisure time was associated with lower BMI values, while a positive association was observed between TV viewing time and BMI.

High BMI values and its association with gender differs between studies, with some suggesting that men have an increased chance of becoming obese ${ }^{16}$, while other studies reported a greater probability among women ${ }^{17}$. The reason behind these differences in scientific literature are not entirely clear, perhaps this occurs because changes in BMI may be influenced by individual factors, such as genetic aspects ${ }^{11}$, as well as by environmental factors ${ }^{18}$. We observed that among Brazilian workers, women had lower BMI compared to men. This result may be explained, at least partially by the hypothesis that women take better care of their health ${ }^{19}$, while men tend to exhibit more simultaneous risk behaviors such as irregular consumption of fruits and vegetables, physical inactivity, and abusive consumption of alcohol and cigarettes ${ }^{20}$, which may lead to a higher BMI in this group. Our findings also sup- port that BMI increases with age, as observed in other study ${ }^{21}$. Some factors may be related to increased BMI with age, such as behavioral factors related to lifestyles that change throughout life, as well as physiological issues related to the decreased basal energy expenditure ${ }^{22}$.

The present study and previous studies showed an inverse and linear association between BMI and leisure-time $\mathrm{PA}^{22}$. Thus, having a healthy $\mathrm{BMI}(<25$ $\left.\mathrm{kg} . \mathrm{m}^{2}\right)$ seems to be associated with a greater chance of leisure-time PA compared to an unhealthy $\mathrm{BMI}^{22-24}$. Furthermore, encouraging the practice of PA can improve the health and consequently the productivity of industrial workers. However, beyond educating workers about the importance of leisure-time PA, public policies and company policies should also help to achieve this goal. Practical strategies can be created to reduce excessive periods of static and repetitive activities in the workplace, encourage more active leisure time for workers, create academies/gyms inside the company, and establish partnerships with academies/gyms outside the company so that the workers can access them. Sports activities such as organizing soccer matches and running teams could also benefit companies and their workers.

The literature has shown association of BMI with sedentary behavior, mainly TV viewing in adults ${ }^{25,26}$. A systematic review found that 9 of 15 studies on sedentary behavior (questionnaires and accelerometers) and BMI demonstrated a positive association between the two $^{27}$. It seems that watching TV for more than 2 hours per day is positively associated with high BMI values, overweight and obesity ${ }^{23,25,26}$. This relationship occurs due to factors, such as physiological aspects (e.g. decrease in lipase activity ${ }^{25}$, decreased PA to the detriment of sedentary time ${ }^{28}$, and an increase in calorie intake from snacking in front of the $\mathrm{TV}^{29}$. Thus, in addition to encouraging an increase in leisure-time PA in Brazilian industrial workers, it is also important to encourage the reduction of TV viewing time, which seems to be harmful to health regardless of the practice of $\mathrm{PA}^{23}$.

With these results, we can understand the relationship between BMI and sociodemographic and behavioral factors in Brazilian adult industrial workers. Thus, we hope that our results can help in directing future interventions and policies aimed at this population, with the purpose of improving health and reducing the burden on health care systems. It seems that men and older workers could benefit more from new strategies to increase PA and decrease TV viewing time. New strategies to promote physical activities such as sports and 
fitness-related activities and other active leisure opportunities could improve workers' body composition.

This study has some limitations that have to be considered such as self-reported measures that may have underestimated the weight and overestimated the height. Meanwhile, other authors have demonstrated the acceptable validity of these measures in this population $^{30}$. Another limitation of our study is that the data was collected approximately 10 years ago. However, we found that leisure-time PA and sedentary behavior are important behaviors associated with the body composition of Brazilian workers. Although the study design does not allow determining causality, our findings strongly suggest that these associations exist. Thus, we suggest that future studies monitor workers' behaviors in a prospective manner to identify possible changes in these behaviors and their health impacts, while considering longitudinal changes in the different aspects and environments of these workers' lives. Nonetheless, it is also worth highlighting the strengths of our study, such as the representative sample of Brazilian industrial workers and that it was conducted in a middle-income country.

BMI tends to be higher among men, older individuals, and those who do not engage in leisure-time PA and watch more hours of TV per day. The identification of the association of modified factors, such as leisure-time PA and sedentary behavior, with the body composition of Brazilian workers is important because public and industrial policies aimed at improving and maintaining the health of the worker can be formulated. We highlight the fact that performing PA at least once a week already shows signs of a reduction in BMI. It is suggested when possible to stimulate and enable leisure-time PA with the purpose of encouraging PA without directing actions to comply with the recommendation of 150 minutes per week, but with the understanding that some activity is better than none. Additionally, reducing TV viewing time among workers to less than two hours per day could be emphasized as a strategy to reduce BMI. We highlight the importance of our findings as few studies in emerging countries have utilized countrywide samples of workers.

\section{Conflict of interest}

The authors declare no conflict of interest.

\section{Research Funding}

The research had institutional and logistical support of Social Service Industry (SESI).

\section{Authors' contribution}

Santos PC, conceived, analyzed data and drafted the first version of the paper. Silva KS, collaborated in the critical review and in designing the Project. Costa BGG, contributed to the writing, analysis and interpretation of the data. Mello GT, contributed to the writing of the article. Oliveira ESA and Nahas MV, collaborated in the critical review and in designing the Project.

\section{References}

1. $\mathrm{Ng}$ M, Fleming $\mathrm{T}$, Robinson $\mathrm{M}$, Thomson B, Graetz $\mathrm{N}$, Margono C, et al. Global, regional, and national prevalence of overweight and obesity in children and adults during 19802013: a systematic analysis for the global burden of disease study 2013. Lancet. 2014;384(9945):766-81.

2. Withrow D, Alter DA. The economic burden of obesity worldwide: a systematic review of the direct costs of obesity: The direct healthcare costs of obesity. Obes Rev. 2011;12(2):131-41.

3. Oliveira ML, Santos LMP, da Silva EN. Direct healthcare cost of obesity in Brazil: an application of the cost-of-illness method from the perspective of the public health system in 2011. PloS One. 2015;10(4):e0121160.

4. Kudel I, Alves JS, Menezes GT, Kull K, NE. The association between body mass index and health and economic outcomes in Brazil. Diabetol Metab Syndr. Diabetol Metab Syndr. 2018;10(1):20.

5. Holtermann A, Krause N, van der Beek AJ, Straker L. The physical activity paradox: six reasons why occupational physical activity (OPA) does not confer the cardiovascular health benefits that leisure time physical activity does. Br J Sports Med. 2018;52(3):149-50.

6. Cohen A, Baker J, Ardern CI. Association between Body Mass Index, Physical Activity, and Health-Related Quality of Life in Canadian Adults. J Aging Phys Act. 2016;24(1):32-8.

7. Ul-Haq Z, Mackay DF, Fenwick E, Pell JP. Association between body mass index and mental health among Scottish adult population: a cross-sectional study of 37272 participants. Psychol Med. 2014;44(10):2231-40.

8. BRASIL CC. Lei no 8.080, de 19 de setembro de 1990. Dispõe sobre as condições para a promoção, proteção e recuperação da saúde, a organização eo funcionamento dos serviços correspondentes e dá outras providências. Diário Oficial da União. 1990;128(182).

9. Xie YJ, Stewart SM, Lam TH, Viswanath K, Chan SS. Television viewing time in Hong Kong adult population: associations with body mass index and obesity. PLoS One. 2014;10;9(1):e85440.

10. WHO Commission on Social Determinants of Health, World Health Organization, editors. Closing the gap in a generation: health equity through action on the social determinants of health: commission on social determinants of health final report. Geneva, Switzerland: World Health Organization, Commission on Social Determinants of Health; 2008.

11. Conklin AI, Ponce NA, Frank J, Nandi A, Heymann J. Minimum Wage and Overweight and Obesity in Adult Women: a multilevel analysis of low and middle income countries. Schooling CM, editor. PLoS One. 2016;11(3):e0150736.

12. Garcia LMT, Silva KS, Duca GFD, Costa FF, Nahas MV. Sedentary Behaviors, Leisure-Time Physical Inactivity, and Chronic Diseases in Brazilian Workers: a cross sectional study. J Phys Act Health. 2014;11(8):1622-34. 
13. Barros MV. Atividades físicas no lazer e outros comportamentos relacionados à saúde dos trabalhadores da indústria no estado de Santa Catarina, Brasil [Master degree Thesis]. Florianopolis: Universidade Federal de Santa Catarina; 1999.

14. Silva KS, Garcia LMT, Rabacow FM, Rezende LFM, Sá TH. Physical activity as part of daily living: Moving beyond quantitative recommendations. Prev Med. 2017;96:160-2.

15. Brasil, Ministério da Saúde. Secretaria de Atenção à Saúde. Departamento de Atenção Básica. Guia alimentar para população brasileira. 2a edição. Brasilia: Ministério da Saúde; 2014.

16. Kritsotakis G, Psarrou M, Vassilaki M, Androulaki Z, Philalithis AE. Gender differences in the prevalence and clustering of multiple health risk behaviours in young adults. J Adv Nurs. 2016;72(9):2098-113.

17. Silva JA, Silva KS, Del-Duca GF, Santos PC, Wolker S, Oliveira ESA, et al. Moderating effect of gross family income on the association between demographic indicators and active commuting to work in Brazilian adults. Prev Med. 2016;(6):87-51.

18. Schule SA, von Kries R, Fromme H, Bolte G. Neighbourhood socioeconomic context, individual socioeconomic position, and overweight in young children: a multilevel study in a large German city. BMC Obes. 2016;3:25.

19. Courtenay WH. Constructions of Masculinity and their Influence on Men's Well-Being. Coll Men Masculinities Theory Res Implic Pract. 2010;307.

20. Loch MR, Bortoletto MSS, Tanno de Souza RK, Mesas AE. Simultaneidade de comportamentos de risco para a saúde e fatores associados em estudo de base populacional. Cad Saúde Colet. 2015;23(2):180-7.

21. Segheto W, Hallal PC, Marins JCB, Silva DCG da, Coelho FA, Ribeiro AQ, et al. Fatores associados e índice de adiposidade corporal (IAC) em adultos: estudo de base populacional. Cienc Saude Colet. 2018;23(3):773-83.
22. Morseth B, Jacobsen BK, Emaus N, Wilsgaard T, Jorgensen L. Secular trends and correlates of physical activity: The Tromso Study 1979-2008. BMC Public Health. 2016;16(1).

23. Pavey TG, Peeters GMEE, Gomersall SR, Brown WJ. Long-term Effects of Physical Activity Level on Changes in Healthy Body Mass Index Over 12 Years in Young Adult Women. Mayo Clin Proc. 2016;91(6):735-44.

24. Salmon J, Bauman A, Crawford D, Timperio A, Owen N. The association between television viewing and overweight among Australian adults participating in varying levels of leisure-time physical activity. Int J Obes. 2000;24(5):600.

25. Tremblay MS, Colley RC, Saunders TJ, Healy GN, Owen N. Physiological and health implications of a sedentary lifestyle. Appl Physiol Nutr Metab. 2010;35(6):725-40.

26. Jones SA, Wen F, Herring AH, Evenson KR. Correlates of US adult physical activity and sedentary behavior patterns. J Sci Med Sport. 2016;19(12):1020-7.

27. Wirth K, KlenkJ, Brefka S, Dallmeier D, Faehling K, Roqué F, et al. Biomarkers associated with sedentary behaviour in older adults: a systematic review. Ageing Res Rev. 2017;35:87-111.

28. Prince SA, Saunders TJ, Gresty K, Reid RD. A comparison of the effectiveness of physical activity and sedentary behaviour interventions in reducing sedentary time in adults: a systematic review and meta-analysis of controlled trials. Obes Rev. 2014;15(11):905-19.

29. Tumin R, Anderson SE. Television, Home-Cooked Meals, and Family Meal Frequency: associations with adult abesity. J Acad Nutr Diet. 2017 Jun;117(6):937-45.

30. Peixoto MRG, Benício MHDA, Jardim PCBV. Validity of self-reported weight and height: the Goiânia study, Brazil. Rev Saude Publica. 2006;40(6).

Received: 30/05/2018

Approved: 18/11/2018

Quote this article as:

Santos PC, Silva KS, Costa BGG, Mello GT, Oliveira ESA, Nahas MV. Behavioral and sociodemographic correlates of the body mass index in Brazilian workers. Rev Bras Ativ Fís Saúde. 2018;23:e0042. DOI: 10.12820/rbafs.23e0042 